\title{
Effect of Activity-Based Environmental Education on the Environmental Identities of Classroom Pre-service Primary School Teachers
}

\author{
Elçin AYAZ1 \\ Dicle University, \\ Diyarbakır TURKEY
}

\author{
Okan DORUK ${ }^{2}$ \\ Gazi University, Ankara \\ TURKEY
}

\author{
Rabia SARIKAYA ${ }^{3}$ \\ Gazi University, Ankara \\ TURKEY
}

${ }^{1}$ Corresponding author: Res.Asst.. Dicle University, Faculty of Education, Division of Classroom Education, Diyarbakır, TURKEY. elcin.ayazz@gmail.com. ORCID: 0000-0003-2488-6777

2 Res. Asst.. Gazi University, Faculty of Education, Division of Classroom Education, Ankara, TURKEY okandoruk@gazi.edu.tr. ORCID: 0000-0001-6264-765X

3 Prof. Dr.. Gazi University, Faculty of Education, Division of Classroom Education, Ankara, TURKEY. rabiasarikaya@gmail.com. ORCID: 0000-0001-9247-8973

\section{Abstract}

This study aims to examine the effects of activity-based teaching on the development of environmental identities of pre-service primary school teachers and to reveal their views on this method. In this study, which was carried out by the explanatory approach of the mixed-methods research model, activity-based teaching was applied in Environmental Education Course. The sample of the study was selected in an easily accessible way and consists of 46 pre-service teachers enrolled in the Department of classroom teaching of a State University in Central Anatolia in Turkey. Applications were made in the spring semester of the 2018-2019 academic year. Dependent groups t-test from parametric tests was used in the analysis of quantitative data. A statistically significant difference was found between the pre-test $(\bar{x}=127.47)$ and post-test $(\bar{x}=134.41)$ total average scores that the pre-service primary school teachers took from the Environmental Identity Scale $(\mathrm{p}<.05)$. In addition to its statistical significance between the pre and post tests, the effect size was also looked at, and the Cohen-d value was found to be 0.43 . Also, to collect the qualitative data, the participants were asked an open-ended question about the teaching method used in the implementation, and thus they were asked to state their views on the method. The qualitative data obtained were analyzed by content analysis. In conclusion, it has been found that activity-based Environmental Education positively affects pre-service teachers in cognitive, affective and behavioral terms. The pre-service teachers stated that they enjoyed the activity-based lessons more, that the subjects are more permanent in this way, that their environmental awareness increased, and that they applied many environmentally friendly behaviors in their daily lives. Based on these results obtained in the study, it can be concluded that activity-based Environmental Education can be used to improve the environmental identities.

\section{Keywords}

Activity-Based Environmental Education, Environmental Identities, Sequential Explanatory Mixed-Methods 
An identity contains an individual's traits and characteristics. There are several factors shaping identity, which are products of the physical environment. Identity has cognitive, affective and behavioral consequences because cultural, social, political and economic forces play roles in the development of identity. Our identity is shaped according to social as well as non-social stimuli, such as the people we meet and the places where we live. For instance, cautiousness about environmental threats and the interpretation for them are perceived according to the perspective of the identity of the person who perceives them. Thus, affective and behavioral responses also change due to identity. Giving stronger reactions to the issues concerning us and displaying behaviors compatible with our fundamental attitudes and values are an indicator of it (Devine-Wright \& Clayton, 2012). Identities are formed by self-compassion in which individuals regulate their feelings and thoughts in their activities and reactions (Kitchell, Kempton, Holland, \& Tesch, 2000).

The relationships between individuals' identities and the environment are described by studies in disciplines such as environmental psychology, environmental sociology, environmental science and environmental education (Blatt, 2013; Clayton, 2012). Such disciplines describe the relationships between the environment and identity from their perspectives. Environmental psychology, for instance, considers the connections as the reflections of emotional and moral identity into individuals' relations with the environment. In contrast, environmental sociologists focus on the structure of identity development in an environment or a community (Clayton, 2003). Environmental identity which is based on the interactions between humans, and natural environment (Clayton \& Opotow, 2003) is defined as the extent to which individuals are loyal to nature or are the individuals' self-perceptions related to nature (Clayton, 2003). The environmental identity focuses on individuals' relationship with nature. Individuals' relationship with the environment can be understood in two different ways, either as "I am a part of the environment" or as "I am separate from the environment" (Schultz \& Tabanico, 2007, p. 1219). Such a relation is called the primary belief. Primary beliefs represent the fundamental truths about individuals' physical and social realities and the nature of their identity. Those fundamental beliefs are used as a reference for the development of more specific attitudes (Schultz, 2001; Kaiser, Hübner \& Bogner, 2005).

Similarities between individuals and their environment should be investigated so as to describe an environmental identity. For example, some cultures believe that there are some similarities between humans, wind and mountains or between humans and some animals. Natural environment influences not only individuals' views and behaviors but also their identity. Therefore, nature-based actions can lead to several differences between "those who wish to interact with nature" and "those who do not wish to interact with nature". Besides, individuals' relationships with nature can also provide predictions about their environmental behaviors (Nisbet, Zelenski, \& Murphy, 2009) because individuals' concerns about the environment are directly related to the degree to which they consider themselves as a part of nature (Schultz, 2001).

Environmental identity is not an abstract concept but is a concept which involves social issues and which is dependent on social development. It changes according to 
how individuals make sense of themselves in nature. Environmental identities are influenced by social factors and by individually gained experience. Therefore, environmental identity is formed in the process, which occurs between social environment and the environment (Clayton, 2003).

We came across differing definitions on examining the studies concerning environmental identity. Thomashow (1995), using the concept of ecological identity instead of environmental identity, describes the concept as "different ways that individuals create in communicating with the world according to personality, values and feelings of self". Additionally, the author also describes the individual reflections of ecological identity. Configuring such an identity focuses on individuals' experiences and is an individual process (Quoted in Williams, \& Chawla, 2016). In a similar vein environmental identity is also described as a part of humans' shaping their concept of self. A sense of adhering to part of natural environment affects the way we perceive this world and our activities towards the world. Environmental identity also contains beliefs about the importance of the environment for us and about who we are and beliefs that we are an important part of the environment (Clayton, 2003).

Many studies concerning the behavioral aspects of the connections between identity and the environment have been conducted in recent years (Vaske \& Kobrin, 2001; Stedman, 2002; Brown, Perkins, \& Brown, 2003; Lewicka, 2005). Various types of behaviors and their definitions were clarified in response to the abovementioned studies. A "typology of environmental preventive behavior" suggested by Stern (2000), for instance, contains collective behaviors such as protesting or collecting signatures and individual habits such as recycling, travelling behaviors and energy consumption. Stern's typology shows ways to associate identities with certain forms of behavior (Quoted in Devine-Wright \& Clayton, 2010). Similarly, individual researchers also argue that environmental identity can be associated with environment-related behaviors (Blatt, 2013; Clayton, 2003) because individuals act consistently with their identity (Kempton \& Holland, 2003). Environmental identities are said to have direct effects on environmental behaviors and indirect effects on environmental attitudes by describing environmental identity as "meanings which are associated with the self which is related to the environment" (Stets \& Biga, 2003). Mannetti, Piero, and Livi (2004) state that identities also contain describing consumer behaviors such as buying fashionable watches, trendy handbags and phones. In addition to that, Clayton (2003) also calls attention to another dimension of environmental identity and points out that individuals with stronger environmental identity have less difficulty in deciding in cases of dilemma related to the environment and that they made more responsible decisions.

Some of the studies were found to focus on students' knowledge and perceptions of the environment (Cheng, Lou, Kuo, \& Shih, 2013; Goralnik, Millenbah, Nelson, \& Thorp, 2012; Kopnina, 2013; Kudryavtsev, Krasny, \& Stedman, 2012; Tsevreni, 2011). There are also studies on the connections between humans and the environment (Clayton, 2003; Blatt, 2013; Gatersleben, Murtagh, \& Abrahamse, 2014; Hinds \& Sparks, 2008; Brock, 2010; Green, Kalvaitis \& Worster, 2015; Mason, 2013; Tanık, 2012). 
Teachers are going to develop an environmental identity in students and who are going to instill in them positive attitudes and behaviors towards the environment. Thus, teachers' and prospective teachers' levels of knowledge about the environment, about how they developed an environmental identity, and about how they will implement Environmental Education when they become practicing teachers are significant. Environmental Education can be improved at every stage, only with good quality teachers (Esa, 2010). Teachers tend to select and design the implementations of Environmental Education in their classes, consistent with their own environmental identity. The meanings teacher assign to their relationship with the environment are also reflected in the process of education in the classroom (Mason, 2013). Therefore, pre-service teachers' environmental identity must be developed.

A close examination of the curricula for primary school Life Sciences, Physical Sciences and Social Studies prepared by the Ministry of National Education in 2018 also makes it clear that environment-related gains are abundant:

In the primary school across 1st, 2nd and 3rd Grades, the "Life Studies" curriculum contains areas of study about environmental issues. In 1st Grade, the focus is on subjects such as plants and animals in the immediate environment, in addition to seasons and their characteristics, and recycling. In 2nd Grade, the focus is on issues such as getting to know the intimate surrounding of the school, also, elements of cultural heritage, the breeding of plants and animals, types of natural events and measures to be taken against natural disasters. In 3rd Grade, students are expected to demonstrate knowledge, skills and values about saving at home, conscious consumer characteristics, historical, natural and touristic places in their immediate surroundings, the growing conditions of fruits and vegetables, the results of human and environmental interaction, and the protection of nature and the environment (MoNE, 2018a).

In the primary school 3rd and 4th Grade "Science Course" curriculum, students are expected to learn about the following environmental issues: to distinguish between living and non-living things; to know about the environment they live in and how to keep it clean, to protect and love it; to observe and explain the natural and artificial environment (school and the environment they live in, environmental cleanliness, nature, forest, park, garden, buildings, national parks, natural monuments, etc.) using examples; to demonstrate thrift in resource use and gaining awareness about savings; and to show individual responsibility about areas such as light pollution, noise pollution, environmental damage of batteries, waste and recycling, etc. Students are expected to learn about such issues and acquire positive attitudes and behaviors (MoNE, 2018b).

In the primary school 4th Grade "Social Studies Course" curriculum, students are expected to learn about the following environmental issues: to realize the limitations of the natural environment and resources, to try to protect natural resources with environmental awareness; and to develop a sustainable environmental understanding (MoNE, 2018c).

It becomes apparent on examining the primary school curricula that pre-service teachers will have to focus on environment-related subjects within the scope of 
various courses when they start their career. Teachers with a well-developed environmental identity can associate several courses with environmental issues, such as mathematics, music, art, and physical education, in addition to those courses mentioned above. Yet, pre-service teachers need to be well educated to achieve this level of understanding. A course on Environmental Education is available in the undergraduate program of the classroom teaching department. However, the course is only theoretical in most of the Faculties of Education. The objective of the course in the undergraduate programs should be both to develop pre-service teachers' environmental identity by instilling in them positive attitudes and behaviors besides knowledge of the environment. Also, the course should help them understand how they can contribute to the development of elementary school students' environmental identity when they start teaching profession. It is possible only through activity-based Environmental Education, where practice in addition to theory is available. Activities that pre-service teachers can complete by the course plans, using various methods and techniques are known in activity-based Environmental Education. In this way, rich teaching content makes students active in teaching and the gains available in the curricula will be presented.

In this context, this current study aims to develop the environmental identities of pre-service primary teachers through activity-based Environmental Education. Thus, it aims to develop teacher candidate's environmental identities, and it also gets them to do the activities which they can use in their professional life. The purpose of the study is to seek answers to the following research questions:

1) Are there any significant differences between the study group's pre-test and post-test scores for the environmental identity scale?

2) What are the pre-service primary school teachers' views on activity-based teaching used in Environmental Education classes?

\section{Methodology}

\section{Research Design}

This study was conducted with 46 pre-service teachers' sophomores taking an Environmental Education course. Within the scope of the study, it was carried out on an activity-based teaching for 14 weeks, and the effect of these practices on preservice teachers' environmental identity was examined. The participants' views on the implementation were also consulted. A sequential explanatory design is the mixed research methods used to collect data in accordance with the purpose of the study. Quantitative statistical significance and how the results are yielded are described in qualitative stages for sequential explanatory design (Cresswell \& Sözbilir, 2018).

Sequential descriptive design includes quantitative $\rightarrow$ qualitative research. In this design, qualitative data is collected after collecting and analyzing predominantly quantitative data. The priority is usually on quantitative data. Qualitative data are obtained mainly to increase quantitative data. Data analysis is interrelated and often combined in data interpretation and discussion sections. This design is particularly 
useful in explaining unexpected research findings or relationships (Cresswell, 2003).

\section{The Study Group}

The study group was composed using a convenience sampling method. Hence, 46 pre-service teachers who attended the classroom teaching department of a state university in the Central Anatolian Region of Turkey during the 2018-2019 academic year were included in the research.

\section{The Process of Implementation}

The implementation of the research was made within the scope of the Environmental Education course with sophomores for 14 weeks in the spring semester of 2018-2019. The "Environmental Identity Scale" was administered to the participants as a pre-test at the beginning of the semester. After that, they were divided into groups of 3-4 on the basis of volunteering. The pre-service teachers were given a list of the subjects to be covered during the semester, and the subjects were assigned to each group by drawing lots. Problems were considered in classes, such as air pollution, global climate change, ozone layer destruction, acid rains, water pollution and drought, soil pollution, genetically modified organisms, organic farming, renewable and non-renewable sources of energy, nuclear contamination, electromagnetic pollution, noise and light pollution, wastes, biodiversity and destruction of it, smuggling of species, ecological footprint as well as major environmental problems. The subject of the week was presented by the lecturer in the first hour of the classes each week throughout the semester. The groups of students did activities related to the subject of the week in the second hour. One or two groups designed activities about the subjects set by drawing lots each week. The pre-service teachers used different methods and techniques (such as drama, discussion, six thinking hats, TGA, etc.) in group activities, and they also included their classmates in the process of teaching and learning. The groups did activities related to the subjects and created active learning environments instead of the theoretical presentation. The pre-service teachers had liabilities to fulfil during active learning activities. The penalties included the following:

1. Whether or not the subjects assigned to the groups are available in primary school Science Course curriculum should firstly be checked while preparing the activities. If the subjects are available in the $3 \mathrm{rd}$ and $4^{\text {th }}$ Grade curricula, activities should be designed by associating them with the gains in the curriculum.

2. If the subject assigned to the groups are not available in the 3rd and 4th-grade curricula, the activities prepared should be suitable to the level of university students.

3. One or more of the root values available in the curricula should absolutely be emphasized (justice, friendship, honesty, self-control, patience, respect, love, responsibility, patriotism, benevolence).

4. Each group should prepare a detailed course plan which contains activities suitable for a constructivist approach. 
The 14-week Environmental Education course was taught to sophomore students of classroom teaching department within the framework of the criteria set above through activity-based implementations, consistent with active learning. The "Environmental Identity Scale" was administered to the pre-service teachers as a post-test at the end of the semester. The pre-service teachers were also asked to write down their views on the way the course was taught.

\section{Data Collection Tools}

The "Environmental Identity Scale" and the semi-structured interview question were used as the tools of data collection in this study.

The environmental identity scale. The "Environmental Identity Scale", which was developed by Clayton (2003) and adapted into Turkish by Clayton and Kılınç (2013) as used in this study to determine pre-service primary school teachers' environmental identities. The items in the scale are related to attitudes towards, and values about. the environment, environmentally friendly behaviors, and personal decisions to be made about the environment in case of conflict. The original version of the scale contained 24 items in a 5-point Likert scale. The Turkish version, on the other hand, was changed into a 7-point Likert scale ranging between 1 (completely false) and 7 (completely true). Clayton and Kılınç (2013) adapted the scale to Turkish and converted it to 7-point Likert type to expand the possible answer range.

The data were collected from 808 participants in the validity and reliability test of the Turkish version of the scale. Clayton and Kılınç did exploratory factor analysis (EFA) and confirmatory factor analysis (CFA) for the validity of the scale. Following the EFA, a scale with four factors labelled as environmental identity (items 3, 9, 10, 11 and 15), the desire to be near to nature (items1, 5, 6, 17, 19 and 20), resembling nature (items 8,12,16,18, 21 and 23) and environmentalist behaviors (items 2, 4, $7,13,14,22$ and 24) emerged. The four-factor structure was confirmed according to the acceptable fit indices which were obtained as a result of CFA which was done to confirm the installation emerging in EFA. Finally, the Cronbach's Alpha reliability coefficient calculated by Clayton and Kılınç for the reliability of the scale was found as 0.88 .

A preliminary implementation was done to use the 24-item, 4-factor Environmental Identity scale, which was adapted into Turkish; and reliability was calculated again for this study. The scale was given to 22 pre-service teachers who were not in the sample for this purpose, and the Cronbach's alpha was found to be 0.83 .

The semi-structured interview question. The participants were asked an open-ended question about the teaching method used in the implementation to collect the qualitative data, and they were asked to state their views on the method. After preparation of the semi-structured interview, necessary corrections were made by obtaining expert opinion. Sufficient time wa given to the students with the aim of collecting detailed data whilst applying the semi-structured interview. 


\section{Data Analysis}

The analysis of quantitative data. The participants' responses to the "Environmental Identity Scale" were marked by the researchers and were transferred to the SPSS program. Descriptive statistics, such as mean average total score and standard deviation, were used. Whether or not the participants' pre-test and post-test scores had normal distribution was analyzed by a Shapiro Wilks test because the number of observations was smaller than 50 . As a result of the test, the value was found as $p>0.05$. Due to the skewness and kurtosis values were between +1 and -1, it was decided that the data fitted for normal distribution (Büyüköztürk, 2018). In addition to that, the data were assumed to have normal distribution according to the central limit theorem since the sample size was $n>30$ (Russell \& Purcell, 2009).

Dependent groups t-tests, were one of the parametric tests used in analyzing the effects of activity-based teaching on the development of pre-service teachers' environmental identity. Effect size beside the statistical significance between pretest and post-test was checked in this study. The Cohen-d value was calculated to determine the effect size. The classification of levels made by Cohen (1992) (0.200.50: small, 0.50-0.80: medium, bigger than 0.80: large) was taken into consideration in calculating the effect size.

The analysis of qualitative data. The qualitative data was put to content analysis (Ylldırım \& Şimşek, 2008). Codes and categories were distinguished in the qualitative data. Additionally, the participants' statements were directly quoted in the findings sections.

Content analysis conducted in this study includes the processes of describing the facts, classifying them and describing how the concepts are related to each other. The data collected in the definition phase, which is the first stage of content analysis, was examined in detail and codes were extracted from the events and facts that were frequently repeated in the data set or that the participant emphasized. In classification, which is the second stage in content analysis, categories are obtained from the determined codes, and themes are obtained from the categories. Briefly, data (codes) that are determined to be similar and related to each other are brought together within the framework of certain concepts (categories) and themes and interpreted. As a result of examining the categories, their relations with each other are revealed and themes are mentioned when these relationships require a higherlevel grouping. Only codes and categories were created in this research. In the third stage, comments were made to interpret the data, establish cause-effect relationships, explain the relationships between the findings and explain the importance of the results obtained (Bengtsson, 2016).

In this study, in order to strengthen the internal validity, attention was given to ensuring there was enough time between test applications so students would not remember the tests. Considering that the long interaction process increases internal validity in conjunction with this study lasting 14 weeks, it was assumed this period of time positively affected internal validity. Participants are all second-year students who can mature at approximately the same rate during the application period. In 
Ayaz, E., Doruk, Z., Sarıkaya, R. (2021). Effect of activity-based environmental education on...

addition, expert opinion about the data collection tools used in the application was received.

\section{Findings}

\section{The Quantitative Findings}

The participants were given the "Environmental Identity Scale" before and after the implementation to reveal the effects of activity-based Environmental Education on pre-service teachers' environmental identity.

The average scores that the pre-service teachers received from the environmental identity scale before and after the implementation were analyzed through dependent groups t-test whose presuppositions were met. Findings obtained from the analysis are shown in Table 1.

Table 1

The Average Scores Pre-Service Teachers Received from the Environmental Identity Scale Prior To and After the Implementation.

\begin{tabular}{lccllll}
\hline & $\mathrm{N}$ & $\overline{\mathrm{x}}$ & $\mathrm{ss}$ & $\mathrm{sd}$ & $\mathrm{t}$ & $\mathrm{p}$ \\
\hline Pre-test & 46 & 127.47 & 15.67 & 45 & 3.23 & $0.002^{*}$ \\
\cline { 1 - 4 } $\begin{array}{l}\text { Post- } \\
\text { test }\end{array}$ & 46 & 134.41 & 16.10 & & & \\
\hline
\end{tabular}

${ }^{*} \mathrm{p}<0.05$

An examination of the average scores that the participants received from the scale before to and after the implementation showed that the average for the total scores they had received from the post-test $(\bar{x}=134.41)$ was higher than the average for the total scores they had received from the pre-test ( $\bar{x}=127.47)$. The rise in the average score indicated that the implementation was influential.

Dependent groups $t$ test- one of the parametric tests- was also done to evaluate the differences between the pre-test and post-test average total scores statistically, and the difference was found to be statistically significant in favor of the post-test, and thus, $t(45)=3.23, p<0.05$. The effect size in addition to statistical significance of the difference between pre-test and post-test scores were also checked and accordingly Cohen-d was found as 0.43 . The value indicates size of almost medium effect. Based on the result, the pre-service teachers can be said to have relatively strong environmental identity.

It was found on examining the sub-factors of the "Environmental Identity Scale" that the factor of desire to be near to nature $(\bar{x}=146.34 \pm 2.73)$ was the most important factor for pre-service teachers. Also, the factor of environmental identity $(\overline{\mathrm{x}}=143.2 \pm 8.01)$ was the second most important factor, and the third most important factor was environmentalist behaviors $(\bar{x}=135.71 \pm 11.74)$. The factor with the lowest average, however, was the factor of resembling nature $(\bar{x}=134.16 \pm$ 17.50). The result demonstrated that personal and profound identity factors such as considering responsible behaviors towards nature as a part of their moral structure were influential in the shaping of pre-service teachers' environmental identity. 
The Cronbach's Alpha reliability coefficient for the 46 participants' post-test scores was calculated as 0.90 while it was found as 0.72 for the factor of environmental identity, as 0.69 for the factor of resembling nature, as 0.74 for the factor of environmentalist behaviors and as 0.75 for the factor of desire to be near to nature.

\section{The Qualitative Findings}

The qualitative data collected from the pre-service teachers focused on their answers to the following question: "What are the pre-service primary school teachers' views on teaching through activity-based teaching used in environmental education classes?" The responses were put to content analysis and the codes and categories were distinguished.

The participants' responses were coded as cognitive contributions, affective contributions and behavioral contributions by the researchers, and the frequencies for the distribution of codes and categories are shown in Table 2.

Table 2

The Pre-Service Primary School Teachers' Views On Teaching The Environmental Education Course In Activity-Based Teaching

\begin{tabular}{|c|c|c|}
\hline Categories & Codes & Participants \\
\hline \multirow{5}{*}{$\begin{array}{l}\text { Cognitive } \\
\text { contributions }\end{array}$} & Instructive & P3,P11,P16,P18,P22,P26,P30,P33,P37 \\
\hline & Reinforcing & $\begin{array}{l}\text { P2,P5, } \\
\text { P9,P11,P13,P15,P22,P34,P35,P38,P39,P40,P46 }\end{array}$ \\
\hline & Efficient & $\mathrm{P} 1, \mathrm{P} 4, \mathrm{P} 6, \mathrm{P} 10, \mathrm{P} 16, \mathrm{P} 18, \mathrm{P} 19, \mathrm{P} 35, \mathrm{P} 36, \mathrm{P} 39, \mathrm{P} 43, \mathrm{P} 46$ \\
\hline & $\begin{array}{l}\text { Difficulty in } \\
\text { finding activities }\end{array}$ & P9,P16,P34 \\
\hline & $\begin{array}{l}\text { Difficulty of the } \\
\text { course }\end{array}$ & P4,P5,P7,P18 \\
\hline \multirow{3}{*}{$\begin{array}{l}\text { Affective } \\
\text { contributions }\end{array}$} & Enjoyable & P8,P10,P20 \\
\hline & Pleasant & P2,P4,P6,P18,P22,P27,P36,P40, P45 \\
\hline & Nice & P3,P10 \\
\hline \multirow{3}{*}{$\begin{array}{l}\text { Behavioral } \\
\text { contributions }\end{array}$} & $\begin{array}{l}\text { Environmental } \\
\text { consciousness }\end{array}$ & P1,P19,P23,P24,P26,P28,P29,P32,P38 \\
\hline & $\begin{array}{l}\text { Preparing to } \\
\text { teaching } \\
\text { profession }\end{array}$ & P6,P11,P13,P14,P16,P19,P20,P43,P46 \\
\hline & Values education & P25,P33,P37 \\
\hline \multicolumn{3}{|c|}{ Those which cannot be divided into categories } \\
\hline \multicolumn{2}{|c|}{ Difficulty in working in groups } & P7,P8,P18,P21,P22,P25 \\
\hline \multicolumn{2}{|c|}{ Advantages of working in groups } & P5,P10,P23,P27,P30,P33,P38,P44,P45 \\
\hline \multicolumn{2}{|c|}{$\begin{array}{l}\text { Suitability of the subjects to the } \\
\text { curriculum }\end{array}$} & P10,P14 \\
\hline
\end{tabular}

As clear from Table 2, the pre-service teachers stated the cognitive contributions related to activity-based teaching that caused changes in their knowledge and perspective of environmental problems: that it increased their environmental consciousness, and that it contributed to them in obtaining permanent knowledge and in forming a broad perspective that caused them to gain 
new ideas. Some of the statements made by the participants in this respect were as in the following:

P3: "I have learnt so many new things that I had never heard before, thanks to the Environmental Education course. I think students' doing the activities in the second part of the class will contribute to us- the pre-service teachers- in positive ways."

P6: "I think that it is an efficient course because we need to gain a sense of the environment and because we will also need to teach in kids such the sense of the environment. The course taught me several things about what I should do and what I should not do even at this age of mine. Besides, I also think that informing us beforehand and then getting us to do the activities is beneficial. The ideas for activities that we can do with our students in the future were created in our mind. In this way, children will learn, have fun, get pleasure and will have a sense of the environment by seeing."

In terms of affective contributions, the pre-service teachers said that their sensitivity to the environment increased, that the classes were taught in a more enjoyable way and that the classes changed their feelings and thoughts about environmental problems. Some of the views stated by the participants in this respect were as in the following:

P 20: "It was one of the courses that I liked the most during the semester. I think that the classes were taught very nicely, effectively and efficiently. Working in groups was also efficient in that it reduced workload and that new ideas emerged."

P 45: "Teaching the classes through activities even though the course was extremely verbal according to the curriculum caused us to have a wonderful semester. Having a great number of activities in classes both enabled us to focus our attention on the courses more and made us have fun while learning."

P 8: “The Environmental Education course was enjoyable for me throughout the semester. We learnt new and useful knowledge that we could use all through our life in each course."

P 10: "I had prejudices when I first came to the class. Having a theoretical course content frightened me at the beginning. But I warmed up as the time passed by and as we did activities as group assignments. It also caused my ability to get on with my classmates to emerge again. We both had fun, and we got used to each other while working with my friends in the group... As to what we learnt, we learnt more about the environment. I started to be a bit more sensitive. Animals, insects which experience life cycle.... For example, insects... I dislike them, but I kept away from things that threaten them when I learnt that they were necessary for us and for nature. I tried to understand nature over and over again. My respect, my empathy and sensitivity to nature and to the creatures in nature increased again. I want to thank the teacher for teaching the course in this way."

The pre-service teachers said, to the behavioral contributions, that their behaviors towards the environment had changed, that they made efforts to prevent environmental problems that they began to pay more attention to recycling, that they gained teaching experience and that their communication and cooperation skills developed. They made statements as in the following:

P 11: "Doing activities at primary school level in classes of environment will lead me in the future. Even though having the course in applied form caused me difficulty, it made me understand several things that we would need to do when we became teachers. First presenting the course and then doing the activities made learning in classes more permanent. It contributed greatly to use..." 
P 19: "I have understood nature and the relations between nature and living creatures thanks to the Environmental Education course. I noticed that our activities could have positive or negative effects on natural balance. I started to be more careful in daily life, not to cause negative effects on natural balance. I am careful even with the products I consume. I choose the products by looking at their content. Besides, I also began to use the recycling and waste boxes-, which I had never used before- thanks to the course. I understood that it was in our hands to leave a livable world to the next generations. In short, the environmental education course made me gain consciousness of nature, and now I am a more conscious person."

P 46: "It is a course which is necessary not only for us but also for every individual in understanding and making sense of the language of nature. Beyond theoretical knowledge, we acquired many permanent behaviors, which we could use in daily life. Having active students is a desirable form of learning in teaching classes."

P 1: "Your classes contributed to use in many ways. I want to thank you for the things you made us gain in your classes. You can be sure that the children we will raise will also be good individuals. You taught us, and you also taught use how to teach children."

P 33: "I learnt that values should be taught in courses even though subjects can be diverse. I also learnt that values could be taught in the form of activities and within classes latently. I learnt a lot about the environment."

P 23: "I believe that the Environmental Education course which I took this semester was very efficient. The teacher teaching the subject and the students researching the subjects and doing activities was very beneficial. Effective and permanent learning occurred in this way."

P 38: "I think that the course contributed to us in such issues as being conscious of the environment, behaving sensitively and using the sources of energy in the right way. We learnt the ways many living and non-living things in our environment contributed to our life and the working of the universe. I learnt a lot of things that I had not known before at the end of this course."

Apart from that, the participants also mentioned the difficulties and advantages of working in groups; and they also said that the subjects were consistent with the curriculum. To sum up, activity-based teaching affected pre-service teachers in positive ways in cognitive, affective and behavioral aspects. They also stated that the method used enabled them to learn permanently, that doing activities through active participation was more amusing and increased their motivation. The participants' answers to the question indicated that almost all of the pre-service teachers' environmental identity was developed and that their knowledge and feelings about environmental problems and their behaviors directed to preventing those problems had changed in positive ways. The inference that the pre-service teachers' behaviors had changed was made on the basis of the intentions they had while making their statements.

\section{Result and Discussion}

This study conducted over 14-weeks focused on activity-based teaching with 46 pre-service primary school teachers who were sophomore students. The study investigated the effects of implementation on the pre-service teachers' environmental identity. Also, the opinions of the pre-service teachers were considered about the applications.

Based on the results, the difference between the participants' environmental identity pre-test and post-test total mean scores were statistically significant and 
that Cohen-d value of 0.43 had an almost medium effect, $t(45)=3.23, p<0.05$. It can be said in this case that pre-service teachers have a relatively strong environmental identity. Similarly, Saraç (2018) also conducted a study on developing pre-service primary school teachers' environmental identities through socio-scientific issuebased Environmental Education and on reducing their materialistic tendencies towards the environment by using the design of action research. The study found statistically significant differences between the pre-test and post-test scores of the pre-service teachers in the "Environmental Identity Scale". Another finding obtained was that the pre-service teachers had positive views on teaching through socioscientific issue-based Environmental Education and that they did not make materialistic statements while making statements which were the positive indicators of environmental identity.

When the sub-factors of the "Environmental Identity Scale" are examined, the "desire to be close to nature" ( $\bar{x}=146.34 \pm 2.73)$ is the most important factor for prospective teachers, while the "environmental identity" ( $\bar{x}=143.2 \pm 8.01)$ is in the second place. The factor of "environmentalist behaviors" ( $\bar{x}=135.71 \pm 11.74)$ is in the third place, and the "resembling nature" ( $\overline{\mathrm{x}}=134.16 \pm 17.50)$ sub-factor is the factor with the lowest average. The situation demonstrated that such personal and profound identity factors as the participants' considering responsible behaviors towards nature as a part of their moral structure were influential in shaping environmental identity. Olivos and Arogenes (2011), in a study, which was conducted to divide the "Environmental Identity Scale into psychometric factors also found that the sub-factor of environmental identity was influential. In a similar study, which was performed in France, the environmental identity levels of 919 higher education students who attended various programs (ecology, other sciences and political sciences) were found.

Accordingly, the students of different programs were found to differ in terms of environmental identity. For example, students of ecology had higher scores than students of political sciences. In addition to that, living in a rural area at childhood explained environmental identity substantially by means of current experiences and by means of nature-related social identity (Prévot, Clayton, \& Mathevet, 2018). Hinds and Sparks (2008), on the other hand, made efforts to determine the roles of emotional ties and environmental identities in interacting with nature. Another study was conducted with the participation of 199 Social Sciences students in England. The participants were given questionnaires to reveal their beliefs about environmental behaviors, their environmental attitudes and their environmental identities. It was found following regression analyses that emotional ties were an independent, significant predictor of intention to interact with the natural environment. Besides, environmental identities were the considerable predictor only in the model where emotional ties were not available. Significant differences were also found to exist between participants who had grown up in rural areas and participants who had grown up in urban areas in terms of the properties analyzed.

According to Devine-Wright and Clayton (2010), identity has cognitive, affective and behavioral implications. Caution to environmental threats and relevant interpretations, for instance, are filtered from the perspective of the individuals who perceive the threats. Affective and behavioral reactions are also displayed 
depending on identity. This current study found that the pre-service teachers' views on teaching the Environmental Education course in activity-based teaching method were related to the factors of cognitive, affective and behavioral contributions. Individuals' positive identity conceptions are essential in terms of environmental consciousness. It was found on examining the candidates' views that the implementations in the scope of the course had influenced their attitudes towards environmental consciousness. Thus, their knowledge and perspectives of environmental problems changed, their environmental consciousness increased and contributed to such areas as obtaining permanent knowledge, forming a broader perspective, developing environmental consciousness and implementing in daily life.

Kempton and Holland (2003) argue that individuals can have positive environmental identities by acting consistently with their identity, and thus, they can display environmental-friendly behaviors. In a similar vein, Dindar (2014) compared the deep beliefs about Environmental Education held by two groups of physical sciences teachers one of which had high levels of environmental identity and the other of which had low levels of environmental identity. As a result, the study found connections between participants with high levels of environmental identity and their deep beliefs about the environment and their deep thoughts about pedagogy. Those participants -as different from the ones with low levels of environmental identity- laid emphasis on such goals as raising environmental consciousness and understanding nature.

The researcher draws attention to environment-based statements made by teachers with high environmental identity- who associate their identity with their teacher identity and state their beliefs about the environment even in a general question such as "what is knowledge?". The researcher's interpretation of the results is that teachers wish to raise individuals with identities similar to their own and that they shaped it in a framework which instead involves feelings and motivation. Similar affective and behavioral statements emerged as positive indicators of environmental identity also in that study.

In a similar way, Blatt (2013) also stresses, in the study in which an Environmental Education course was taught in an activity-based teaching method, that contributions would be made to set up personal ties with nature and to developing a sense of citizenship for the place of living with different perspectives. Socio-scientific issues come into prominence in this respect. One of the essential properties of scientific issues, which concern society- their controversial nature-, is thought to provide opportunities to discuss the individual and social effects related to the environment and to have new experiences in environment-related issues. Individuals will be provided with opportunities to have discussions from a scientific perspective.

The pre-service teachers in this study stated in relation to the factor of behavioral contributions that their behaviors towards the environment changed in many ways. The intention is important in behaviors. Behaviors are a function of intentions. Suppose individuals have the intention to display behavior, the opportunities to demonstrate the behavior increases (Hungerford \& Volk, 1990). Research has also shown that there are strong- at least medium- ties between intentions and behaviors 
(Kaiser, Wölfing, \& Fuhrer, 1999, P. 5). The pre-service teachers who said that they had the intention to solve environmental problems play important roles with their behaviors in the solution of the problems (Alp, Ertepınar, Tekkaya \& Yılmaz, 2008). Tanık (2012) demonstrated that science and technology pre-service teachers had a relatively strong environmental identity and relatively high levels of environmentfriendly behaviors. The study found that psychometric factor involving beliefs, attitudes and behavioral factors such as environmental identity as a whole was influential in displaying environment-friendly behaviors. Gatersleben, Murtagh and Abrahamse (2014) analyzed the roles of values and environmental identities in explaining individual environmentalist behaviors. The data in the three studies were collected from 2694 participants in total.

As a result of the regression and correlation analyses, it was found that values and identities were good predictors of environmentalist behaviors in each study. The results obtained in the studies provided evidence supportive of the thought that environmental identities encouraged sustainable behaviors. Dindar (2014) pointed out that individuals with high environmental identity had more inclinations towards inquiring and constructivist education in the framework of feelings and motivation. Öztarakçı (2019)- in a study of metaphors conducted with classroom, social studies and science pre-service teachers- reported that the pre-service teachers had environmental identities, various perceptions about being environment- friendly, high environment-friendly behaviors and strong environmental identities.

\section{Suggestions}

A review of relevant literature shows that several factors are influential in individuals' environmental identities. Particularly the positive attitudes that individuals will develop towards the environment by making use of nature are essential. Activities to trigger cognitive, affective and behavioral elements are needed for it. Teachers and pre-service teachers will have significant responsibilities in this respect. This paper has revealed pre-service teachers' levels of environmental identity and their views in this respect. Analyzing their situation can contribute to other studies to be performed in this context.

This study was conducted in activity-based teaching, and the implementation was made in the classroom. Future studies can include activities in nature. The study group was composed of pre-service primary school teachers in this study. Other studies can be conducted with the inclusion of elementary school students.

Prévot, Clayton and Mathevet (2018) argue that nature contains significant experiences which contribute to the development of personal identity and that encouraging natural experiences can compensate for natural deficits. It can be necessary to create environments suitable to social structures in research about environmental identity because social variables can be influential in creating an environmental identity. Activities with the content of nature and activities containing sustainable environmental awareness should be included by setting out from the consciousness that individuals are an important part of the natural environment and of the social structure in which they live. Those activities will help them to create a positive environmental identity and to transfer it into their life. 
There were no opportunities to include activities to be done in nature in this study because the classroom environment where the research was conducted and the environmental education course was taught was limited and because the time was also limited. Having longer class hours for applied courses in undergraduate programs and providing suitable environments for them could remove the limitations.

\section{References}

Alp, E., Ertepinar, H., Tekkaya, C., \& Yilmaz, A. (2008). A survey on Turkish elementary school students' environmental friendly behaviours and associated variables. Environmental education research, 14(2), 129-143.

Bengtsson, M. (2016). How to plan and perform a qualitative study using content analysis. NursingPlus Open, 2, 8-14.

Blatt, E. (2013). Exploring environmental identity and behavioral change in an environmental science course. Cultural Studies of Science Education, 8(2), 467-488.

Brock, R. J. (2010). Exploring the development of fourth graders' environmental identity through participation in a semi-formal nature club. Doctoral Dissertation, Nevada University Department of Curriculum, Teaching, and Learning, Nevada.

Brown, B., Perkins, D. D., \& Brown, G. (2003). Place attachment in a revitalizing neighbourhood: Individual and block levels of analysis. Journal of Environmental Psychology, 23(3), 259-271.

Büyüköztürk, Ş. (2018). Manual of data analysis for social sciences. Ankara: Pegem Academy.

Cheng, Y. M., Lou, S. J., Kuo, S. H., \& Shih, R. C. (2013). Investigating elementary school students' technology acceptance by applying digital game-based learning to environmental education. Australasian Journal of Educational Technology, 29(1), 96110.

Clayton, S. (2003). Environmental identity: A conceptual and an operational definition. In S. Clayton \& S. Opotow (Eds.), Identity and the natural environment (pp. 45-65). Cambridge, MA: MIT.

Clayton, S. D. (2012). Environment and identity. Retrieved from: https://doi.org/10.1093/oxfordhb/9780199733026.013.0010.

Clayton, S., \& Kilinç, A. (2013). Proenvironmental concern and behavior in Turkey: The role of national and environmental identity. PsyEcology, 4(3), 311-330.

Clayton, S., \& S. Opotow. (2003). Identity and the natural environment. London: The MIT Press.

Creswell, J. W. (2003). Research design: Quantitative, qualitative, and mixed methods approaches (2nd ed.). Thousand Oaks, CA: Sage.

Creswell, J. W., \& Sözbilir, M. (2017). Karma yöntem araştırmalarına giriş. Ankara: Pegem Academy.

Cohen, J. (1992). Statistical power analysis. Current Directions in Psychological Science, 1(3), 98-101.

Devine-Wright, P., \& S. Clayton. 2010. Introduction to the special issue: Place, identity and environmental behavior. Journal of Environmental Psychology 30(3), 267-70.

Dindar, Y. (2014). Çevre kimliği yüksek ve düşük olan fen bilimleri öğretmenlerinin çevre eğitimi inançlarının klyaslanması [Comparing environmental education beliefs of 
science teachers having low and high environmental identity scores]. Master's Thesis, Abant İzzet Baysal University, Institute of Educational Sciences, Bolu.

Esa, N. (2010). Environmental knowledge, attitude and practices of student teachers. International Research in Geographical and Environmental Education, 19(1), 39-50.

Gatersleben, B., Murtagh, N., \& Abrahamse, W. (2014) Values, identity and pro environmental behaviour, Contemporary Social Science, 9(4), 374-392.

Goralnik, L., Millenbah, K. F., Nelson, M. P., \& Thorp, L. (2012). An environmental pedagogy of care: Emotion, relationships, and experience in higher education ethics learning. Journal of Experiential Education, 35(3), 412-428.

Green, C., Kalvaitis, D., \& Worster, A. (2016) Recontextualizing psychosocial development in young children: A model of environmental identity development. Environmental Education Research, 22(7), 1025-1048.

Hinds, J., \& Sparks, P. (2008) Engaging with the natural environment: The role of affective connection and identity. Journal of Environmental Psychology, 28(2), 109-120.

Hungerford, H. R., \& Volk, T. L. (1990). Changing learner behavior through environmental education. The journal of environmental education, 21(3), 8-21.

Kaiser, F. G., Hübner, G., \& Bogner, F. X. (2005). Contrasting the theory of planned behavior with the value-belief-norm model in explaining conservation behavior. Journal of applied social psychology, 35(10), 2150-2170.

Kaiser, F. G., Wölfing, S., \& Fuhrer, U. (1999). Environmental attitude and ecological behaviour. Journal of Environmental Psychology, 19(1), 1-19.

Kempton, W., \& Holland, D. (2003). Identity and sustained environmental practice. In S. Clayton \& S. Opotow (Eds.), Identity and the natural environment (pp. 317-341). Hong Kong, China: MIT.

Kitchell, A., Kempton, W., Holland, D., \& Tesch, D. (2000). Identities and actions within environmental groups. Human Ecology Review, 7, 1-20.

Kopnina, H. (2013). An exploratory case study of Dutch children's attitudes toward consumption: Implications for environmental education. The Journal of Environmental Education, 44(2), 128-144.

Kudryavtsev, A., Krasny, M. E., \& Stedman, R. C. (2012). The impact of environmental education on sense of place among urban youth. Ecosphere, 3(4), 1-15.

Lewicka, M. (2005). Ways to make people active: The role of place attachment, cultural capital and neighborhood ties. Journal of Environmental Psychology, 25(4),381395.

Mannetti, L., Pierro, A., \& Livi, S. (2004). Recycling: Planned and selfexpressive behaviour. Journal of Environmental Psychology, 24(2), 227-236.

Mason, H. M. (2013). Environment identity development: Exploring the formative experiences and mental models of teachers engaged in environmental education. Master's Thesis, University of Nebraska, Lincoln.

Ministry of National Education. (2018a). T.C. Milli Eğitim Bakanlı̆̆ı Talim Terbiye Kurulu Başkanlığı (Hayat Bilgisi dersi 1, 2 ve 3. sinıflar) öğretim programı. [Republic of Turkey, Ministry of National Education, Head Council of Education and Morality, Life Studies course (1st, 2nd and 3rd grades) curriculum]. Ankara: State Books Directorate Printing House. 
Ministry of National Education. (2018b). T.C. Milli Eğitim Bakanlığı Talim Terbiye Kurulu Başkanlığı (ilköğretim Fen Bilimleri dersi $(3,4,5,6,7$ ve 8. sınıflar) öğretim programı [Republic of Turkey, Ministry of National Education, Head Council of Education and Morality, Elementary Science course (3rd, 4th, 5th, 6th, 7th and 8th grades) curriculum], Ankara: State Books Directorate Printing House.

Ministry of National Education. (2018c). T.C. Milli Eğitim Bakanlığı Talim Terbiye Kurulu Başkanlığı (Sosyal Bilgiler dersi $(4,5,6,7$, ve 8. sinıflar) öğretim programı [Republic of Turkey, Ministry of National Education, Head Council of Education and Morality, Social Studies course (4th, 5th, 6th, 7th and 8th grades) curriculum], Ankara: State Books Directorate Printing House.

Nisbet, E. K., Zelenski, J. M., \& Murphy, S. A. (2009). The nature relatedness scale linking individuals' connection with nature to environmental concern and behavior. Environment and Behavior, 41(5), 715-740.

Olivos, P., \& Aragonés, J. I. (2011). Psychometric properties of the Environmental Identity scale (EID). Psyecology, 2(1), 65-74.

Öztarakçı, D. (2019). Öğretmen adaylarının çevre dostu davranışları ve çevre kimlikleri [Environment friendly behaviors and environmental identity of teachers' pre-service]. Master's Thesis, Balıkesir University Institute of Science.

Prévot, A. C., Clayton, S., \& Mathevet, R. (2018). The relationship of childhood upbringing and university degree program to environmental identity: Experience in nature matters. Environmental Education Research, 24(2), 263-279.

Russell, B. ve Purcell, J. (2009). Online research essentials: designing and Implementing research studies. United States of America: Jossey-Bass, A Wiley Imprint.

Saraç, E. (2018). Sınıf öğretmeni adaylarının çevre kimlikleri ve çevreye yönelik materyalist eğilimleri: Eylem araştırması. Doktora Tezi. Gazi Üniversitesi Eğitim Bilimleri Enstitüsü, Ankara. Schultz, P. W. (2000). New environmental theories: Empathizing with nature: The effects of Perspective taking on concern for environmental issues. Journal of social issues, 56 (3), 391-406.

Schultz, W., \& Tabanico, J. (2007). Self, identity, and the natural environment: Implicit connections with nature. Journal of Applied Social Psychology, 37(6), 1219-1247.

Schultz, W.P. (2001). The structure of environmental concern: Concern for self, other people, and the biosphere. Journal of Environmental Psychology, 21(4), 327-39.

Stedman, R. (2002). Toward a social psychology of place: Predicting behaviour from placebased cognitions, attitude, and identity. Environment and Behaviour, 34,561581.

Stets, J. E., \& Biga, C. F. (2003). Bringing identity theory into environmental sociology. Sociological Theory, 21(4), 398-423.

Tanık, N. (2012). Fen ve teknoloji öğretmen adaylarının çevre kimliklerinin ve çevre dostu davranışlarının belirlenmesi [Determining the environmental identity and proenvironmental behaviours of student science teachers]. Mater's Thesis, Erciyes University Institute of Educational Sciences, Kayseri.

Thomashow, M. (1995). Ecological identity: Becoming a reflective environmentalist. Cambridge, MA: MIT Press.

Tsevreni, I. (2011). Towards an environmental education without scientific knowledge: an attempt to create an action model based on children's experiences, emotions and 
perceptions about their environment. Environmental Education Research, 17(1), 5367.

Vaske, J. J., \& Kobrin, K. C. (2001). Place attachment and environmentally responsible behaviour. Journal of Environmental Education, 32, 16-21.

Williams, C. C., \& Chawla, L. (2016) Environmental identity formation in nonformal environmental education programs, Environmental Education Research, 22(7), 978-1001.

Yıldırım, A., \& Şimşek, H. (2008). Sosyal bilimlerde nitel araştırma yöntemleri 6. Baskı [Scientific research methods in social sciences 6th edition]. Ankara: Seçkin Publishing.

\section{Biographical Statements}

Elçin AYAZ is currently research assistant doctor in the Ziya Gökalp Faculty of Education at Dicle University, Turkey. She worked as a classroom teacher for 4 years before becoming a research assistant and she is working in her profession for 8 years. She worked on her Ph.D. thesis on engineering design-based processes and STEM education in primary school science subjects.

Okan DORUK is currently research assistant in the Gazi Faculty of Education at Gazi University, Turkey. He is a doctoral student in classroom teaching department. He works in the fields of science teaching, history of science and nature of science.

Rabia SARIKAYA is currently full professor in the Gazi Faculty of Education at Gazi University, Turkey. She teaches undergraduate, graduate and doctoral programs in the field of Primary Education. Her areas of expertise include biology, genetics, science and technology laboratory applications, and environmental education. She has many national and international works in the field. 